\title{
Evolution of a shear zone before, during and after melting
}

\author{
Amicia L. Lee ${ }^{1,2 *}$, Geoffrey E. Lloyd ${ }^{1}$, Taija Torvela ${ }^{1}$ and Andrew M. Walker ${ }^{1}$ \\ ${ }^{1}$ School of Earth and Environment, University of Leeds, Leeds, LS2 9JT UK \\ ${ }^{2}$ Department of Geology, University of Tromsø, 9037 Tromsø, Norway \\ (D) ALL, 0000-0003-0067-9183; GEL, 0000-0002-7859-2486; TT, 0000-0003-1539-8755; AMW, 0000-0003-3121-3255 \\ *Correspondence: amicia.lee@uit.no
}

\begin{abstract}
Partial melt in the deforming mid- or lower continental crust causes a strength decrease and drives formation of lithological heterogeneities. However, mechanisms of formation of syn-melt deformation zones and strain partitioning in partially molten rock remain poorly understood. We use field and microstructural observations to unravel the evolution of a partial melt shear zone, Seiland Igneous Province, northern Norway. The Øksfjord shear zone (ØSZ) is one of several paragneiss shear zones present within gabbros of the Seiland Igneous Province, formed by syn-intrusive deep crustal shearing during lithospheric extension related to continental rifting. Microstructures from the ØSZ show evidence for different deformation conditions. The first phase was active pre-melt and involved deformation at high subsolidus temperatures. This was followed by syn-melt deformation of the shear zone causing a relative strength increase towards the shear zone centre upon crystallization. The third phase nucleated two parallel shear zones at the edges of the ØSZ; melt textures are absent and microstructures indicate deformation at lower temperatures and higher stresses. In effect, melt migration towards the shear zone centre ultimately led to strengthening of the shear zone core, with post-crystallization deformation focusing along shear zone margins where significant heterogeneities are present.
\end{abstract}

Supplementary material: Figures illustrating grain boundary dihedral angle data, EBSD maps, grain size distribution and additional pole figures is available at https://oi.org $/ 10.6084 / \mathrm{m} 9$.figshare.c. 4819494

Received 12 July 2019; revised 14 January 2020; accepted 15 January 2020

Experimental studies of partially molten rock show that there is dramatic strength drop when partial melt forms a connected network at c. 7\% melt volume (e.g. Rosenberg and Handy 2005). This strength decrease is propagated as melt volume increases and deformation partitions between the solid rock and liquid melt (Vanderhaeghe 2009). Partial melting is common in the middle to lower continental crust owing to high temperatures, decompression and/or the influence of volatiles promoting pervasive melting (Sawyer 1994; Brown 2001; Vanderhaeghe 2009). Partial melt adds to the heterogeneous nature of these rocks (e.g. grain size, mineralogy, microstructure, etc.), and such lithological heterogeneities are important factors in controlling strain partitioning on all scales (Fossen and Cavalcante 2017). Rheological relationships have been well constrained from experiments; however, experiments do not always explain observed partial melt at outcrop scale in the field or at crustal scale from the geophysical response (Brown et al. 1995; Rosenberg and Handy 2005; Karato 2010; Lee et al. 2017). For example, if melt localizes strain, it is unclear why very large volumes of melt remain in situ within the crust (crystallizing in the form of migmatites), despite their sometimes immediate proximity to one or several shear zones that should act as conduits for melt escape (Labrousse et al. 2004; Lee et al. 2018). Rushmer (2001) showed that a significant volume change during melting can lead to melt migration and extraction from a system, leading to strain hardening. However, if only small volume changes are involved, melt can remain trapped along grain boundaries, resulting in prolonged weakening.

It is important to consider how shear zones evolve through time and what role partial melt plays in their evolution. The active deformation mechanisms and strain localization in partial melt shear zones vary during their evolution from phases of melt-free to synmelt and post-melt deformation. Strain localization is influenced by many parameters within shear zones; for example, pre-existing fractures, weak layers or structures (Passchier 1982; Austrheim and Boundy 1994; Pennacchioni and Cesare 1997), margins of a lithological heterogeneity such as paired shear zones (Pennacchioni and Mancktelow 2007) and thickness change(s) through time (Hull 1988; Means 1995; Vitale and Mazzoli 2008; Pennacchioni and Mancktelow 2018).

In this paper, we investigate the microstructural signature of a syn-intrusive partial melt shear zone from the Øksfjord peninsula in the Seiland Igneous Province of the North Norwegian Caledonides. Deformation of the shear zone occurred at the same time as biotite dehydration melting and granulite-facies metamorphism, where the intrusion of large gabbroic plutons at the base of the lower crust provided the heat source for the high-temperature metamorphism and partial melting (Elvevold et al. 1994; Menegon et al. 2011). Identification of phases of pre-, syn- and post-melt deformation makes the Øksfjord shear zone an ideal system to study the processes and effects of partially molten lower crustal deformation.

\section{Geological setting}

The study area is located in the Sørøy Nappe of the Kalak Nappe Complex of northern Norway (Fig. 1). The Sørøy Nappe comprises variably metamorphosed paragneisses, generally attributed to the Sørøy succession (Kirkland et al. 2006, 2007a, 2008; Corfu et al. 2007, 2011). The Eidvågeid supracrustal sequence (Akselsen 1982) is considered a high-grade, migmatitic part of the Sørøy succession (Kirkland et al. 2007a). The Sørøy succession was deposited between 910 and $840 \mathrm{Ma}$ and subsequently deformed, metamorphosed and intruded by granitic plutons between $850-820$ and $710 \mathrm{Ma}$ (Kirkland et al. 2006, 2007a, 2008; Corfu et al. 2007, 2011; Gasser et al. 2015). The Sørøy succession is intruded by the Seiland Igneous Province, which consists of a suite of deep-seated, riftrelated, mantle-derived magmatic rocks emplaced into paragneisses 

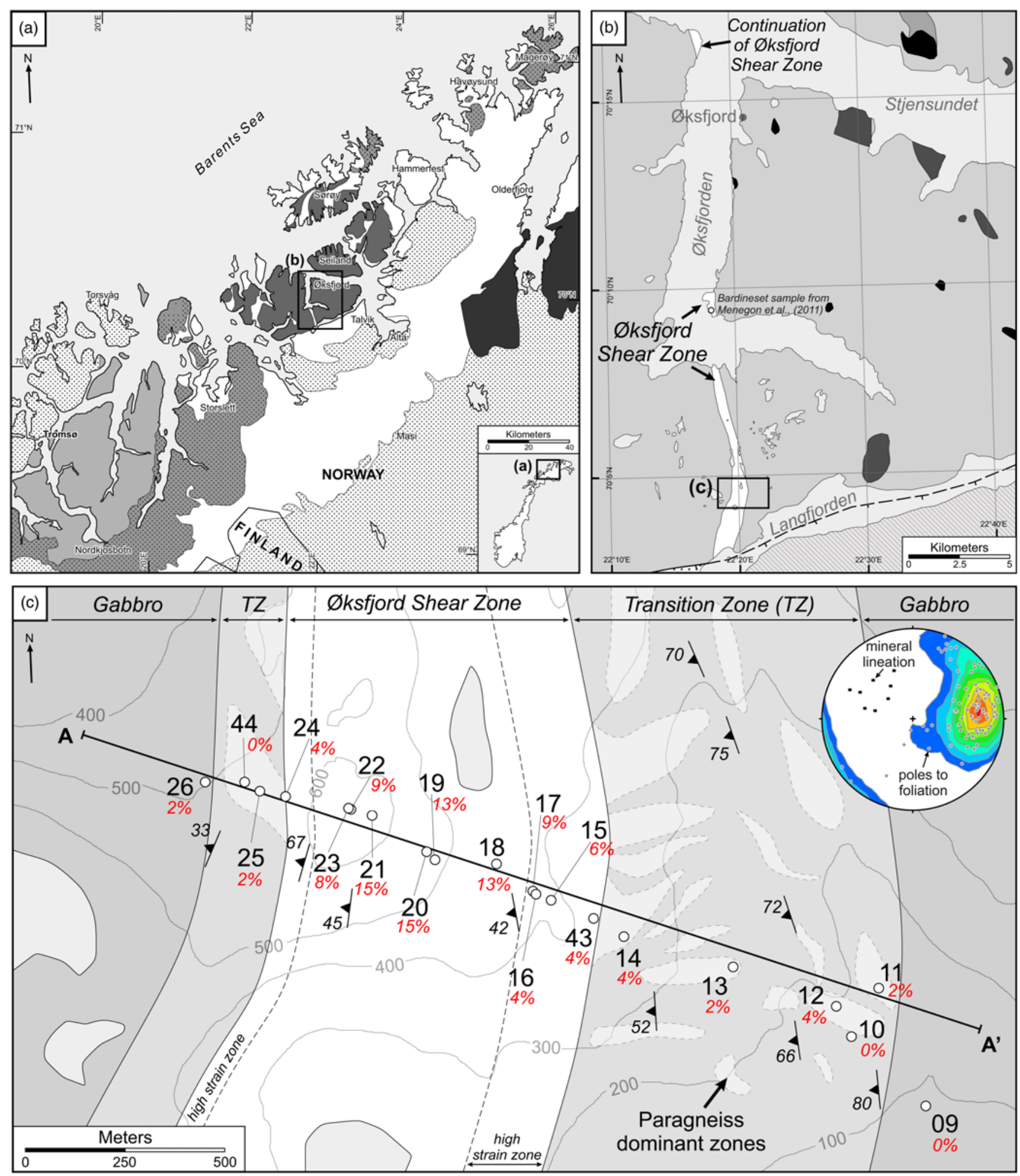

\section{Key to map (a)}

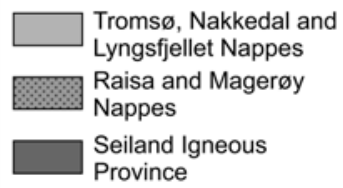
Lyngsfjellet Nappes Raisa and Magerøy

Seiland Igneous

Province

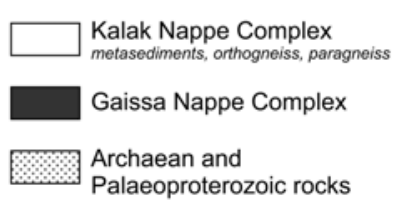

Key to maps (b) and (c)

\begin{tabular}{|c|c|c|c|c|}
\hline & & Seiland Igneous Province & & Vargsund-Langfjord \\
\hline & $\begin{array}{l}\text { Migmatised paragneiss } \\
\text { including Eidvágeid paragneiss }\end{array}$ & Gabbro & & Fault \\
\hline 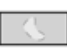 & $\begin{array}{l}\text { Paragneiss-gabbro } \\
\text { transition }\end{array}$ & Peridotite & $\circ 09$ & Sample Location \\
\hline & $\begin{array}{l}\text { Metasediments and } \\
\text { amphibolites }\end{array}$ & Syenite & $\succ 45$ & Gneiss Foliation \\
\hline \% & Metasandstone & Carbonatite & $6 \%$ & Sample melt percent \\
\hline
\end{tabular}

Fig. 1. Geological map of (a) northern Norway and Seiland Igneous Province with inset detail maps of (b) Øksfjord Peninsula in the Seiland Igneous Province and (c) Øksfjord shear zone transect (geological maps modified from Roberts 1973; Slagstad et al. 2006). 
during intracontinental rifting leading to the opening of the Iapetus Ocean at 570-520 Ma (Elvevold et al. 1994; Reginiussen et al. 1995; Roberts et al. 2006a,b).

Intracontinental Iapetus rifting would have been similar to the current East African Rift, where magmatic rocks ranging in composition from ultrabasic to nepheline syenitic and carbonatitic were emplaced into continental crust of the Sørøy Nappe (Ramsay et al. 1985; Krogh and Elvevold 1990; Elvevold et al. 1994; Roberts 2003; Roberts et al. 2006a). The intrusive event was short-lived, between 570 and $520 \mathrm{Ma}$ (Reginiussen et al. 1995; Roberts et al. 2006a). The total extent of magmatism is unknown but was much more voluminous than the current surface exposure of $5400 \mathrm{~km}^{2}$, which represents only the roots of the intrusions (Roberts et al. 2006a). The rift event was followed by the Caledonian Orogeny. In the Kalak Nappe Complex peak metamorphism is constrained to 450-425 Ma (Corfu et al. 2006, 2011; Kirkland et al. 2006, 2007a,b; Gasser et al. 2015), and the underlying Laksefjord and Gaissa Nappes give Caledonian deformation ages up to $500 \mathrm{Ma}$ (Rice and Frank 2003; Sundvoll and Roberts 2003; Kirkland et al. 2008).

The Øksfjord peninsula (Fig. 1b) consists almost entirely of layered gabbro plutons intruded into paragneiss and metapelites of the Eidvågeid sequence (Akselsen 1982; Elvevold et al. 1994; Reginiussen et al. 1995). During the intrusive event, the Eidvågeid gneisses underwent contact metamorphism to peak conditions of $T=930-960^{\circ} \mathrm{C}$ and $P=0.55-0.7 \mathrm{GPa}$ before cooling and recrystallizing at pyroxene granulite-facies conditions at $T=700-750^{\circ} \mathrm{C}$ and $P=0.5-0.7 \mathrm{GPa}$ (Elvevold et al. 1994). A steeply dipping (c. $60^{\circ} \mathrm{WSW}$ ) gneissic to mylonite foliation developed in the metasediments and gabbro during this period of metamorphism, with asymmetric fabrics indicating a top-down-to-NW sense of shear (Menegon et al. 2011). The relationship of magmatic layering to the paragneiss foliation suggests syn-intrusive deep crustal shearing during lithospheric extension (Elvevold et al. 1994; Roberts et al. 2006a). The study area focuses on a $2 \mathrm{~km}$ section through a laterally continuous paragneiss Øksfjord shear zone (ØSZ) on the Øksfjord Peninsula. This shear zone can be traced northward to outcrops on the edge of Øksfjorden (Fig. 1b and c).

Thermodynamic modelling from the continuation of the ØSZ to the north at Bardineset, $c .50 \mathrm{~m}$ from the paragneiss-gabbro contact, shows that the paragneiss and metapelites have undergone shearing and partial melting at metamorphic conditions of $T=760-820^{\circ} \mathrm{C}$ and $P=0.75-0.95 \mathrm{GPa}$ (Menegon et al. 2011) via biotite dehydration $(\mathrm{bt}+\mathrm{pl}+\mathrm{sil}+\mathrm{qz}=\mathrm{kf}+\mathrm{gt}+$ melt; Spear et al. 1999). The paragneiss is segregated into leucosome- and melanosome-rich domains visible from outcrop to microscale. It is estimated that $5-7 \%$ melt was produced during partial melting and shear deformation (Menegon et al. 2011).

\section{Field observations}

Approximately $5 \mathrm{~km}$ from the shear zone boundary the gabbro has long $(3-10 \mathrm{~cm})$ dendritic pyroxene crystals resembling a harrisitic texture. Closer to the shear zone boundary $(0.5-1 \mathrm{~km}$ away) the gabbro lacks the harrisitic texture, the grain size is smaller (up to $1 \mathrm{~cm}$ ) and it has a weak solid-state foliation. The boundary between the gabbro and paragneiss is not distinct, and consists of a c. 100$500 \mathrm{~m}$ wide transition zone (Fig. 1c). The transition zone is dominated by foliated gabbro with 'rafts' of paragneiss that are also foliated, showing stromatic layering with clear mineral segregation. The transition is not a simple linear increase of migmatized paragneiss compared with gabbro.

Figure 2 shows representative outcrop photographs from the gabbro through the transition and into the centre of the ØSZ in the paragneiss. Sample SIP09 is a gabbro in which the foliation is indistinct (Fig. 2a); it marks the edge of the transition zone from where paragneiss is present. SIP13 is an example of the paragneiss texture where it is surrounded by gabbro within the transition zone (Figs $1 \mathrm{c}$ and $2 \mathrm{~b}$ ). The paragneiss rafts are typically up to $10-50 \mathrm{~m}$ in length and they are more common closer to the paragneiss. The paragneiss rafts are isolated blocks and do not exhibit connectivity in the field.

The paragneiss shear zone exhibits a north-south-trending gneissic to mylonitic foliation with a sparse stretching lineation plunging moderately towards the NW. This foliation is parallel to the primary magmatic layering preserved in some areas of the gabbro (Elvevold et al. 1994; Roberts et al. 2006a) but more prominent here owing to the strain imposed by the shear zone.

The paragneiss within the ØSZ has a garnet-granulite mineral assemblage and a higher felsic content than paragneiss rafts within the gabbro. Figure 2c-h show typical outcrop exposures observed in the ØSZ. From the field it is difficult to determine exact areas of melt within the paragneiss; however, the presence of a hightemperature mineral assemblage, more than one type of migmatite texture, and larger 'pools' of leucosome allows inference that the system was melt-bearing. SIP15, located just inside the paragneiss boundary, is a schollen-type migmatite where rafts of nonmigmatized rock and restite remain intact and the leucosome flows around the rafts (Fig. 2c). The paragneiss typically displays stromatic migmatite textures, with layering observed on a variety of scales (SIP17-21; Fig. 2d-f). The stromatic layering of the migmatite shows the segregation of the leucosome (felsic) and melanosome (mafic) stroma of various thicknesses from the millimetre to decimetre scale. The centre of the paragneiss has tabular stroma (e.g. SIP21), although in some places tight parasitic folds deform the stromatic migmatite (e.g. SIP20; Fig. 2e). Layer thickness remains constant in most folded migmatites (Fig. 2e), but in some localities the leucosome varies in thickness and the fold hinges in the restite have thickened to form similar folds. Where present, kinematic indicators in the paragneiss show normal offset shearing top down to both east and west, although top down to the west is more common and suggests oblique sinistral-normal displacement owing to shearing (Fig. $2 g$ and h).

\section{Microstructural analysis}

As some of the leucosome can segregate through solid-state processes as opposed to melting, it is important to consider the microstructure to understand melting processes and volumes. Melting occurred by biotite dehydration, where K-feldspar, garnet and melt are products of the reaction $\mathrm{bt}+\mathrm{qz}+\mathrm{pl}+\mathrm{sil}=\mathrm{melt}+\mathrm{gt}+\mathrm{kf}$ (Fig. 3; Spear et al. 1999; Menegon et al. 2011).

\section{Melt textures}

Relics of a former grain boundary melt are very common in the paragneiss samples and are generally composed of K-feldspar, plagioclase and ilmenite (Fig. 3). Reaction textures of plagioclase and biotite are observed to break down to form K-feldspar, with ilmenite infilling nearby pore space (SIP14; Fig. 3a and b). SIP14 shows fine-grained quartz crystallized between orthopyroxene grains (Fig. 3b). This sample is located in the transition zone, outside the shear zone, and suggests that quartz is a product of melting in this area in addition to K-feldspar, plagioclase and ilmenite. Figure $3 \mathrm{c}$ and $\mathrm{d}$ show areas between plagioclase grains that are filled with fine-grained K-feldspar and biotite (e.g. SIP16, 20). These textures could be evidence of 'back-reaction' of the melting reaction; melt may have occupied this area and upon crystallization the biotite-dehydration melting reaction reversed producing the fine-grained infill.

In addition to grain boundary melting, 'melt zones' are also observed in SIP11 located outside the shear zone in a paragneiss raft. In this sample, complex melt-rock interaction textures are 

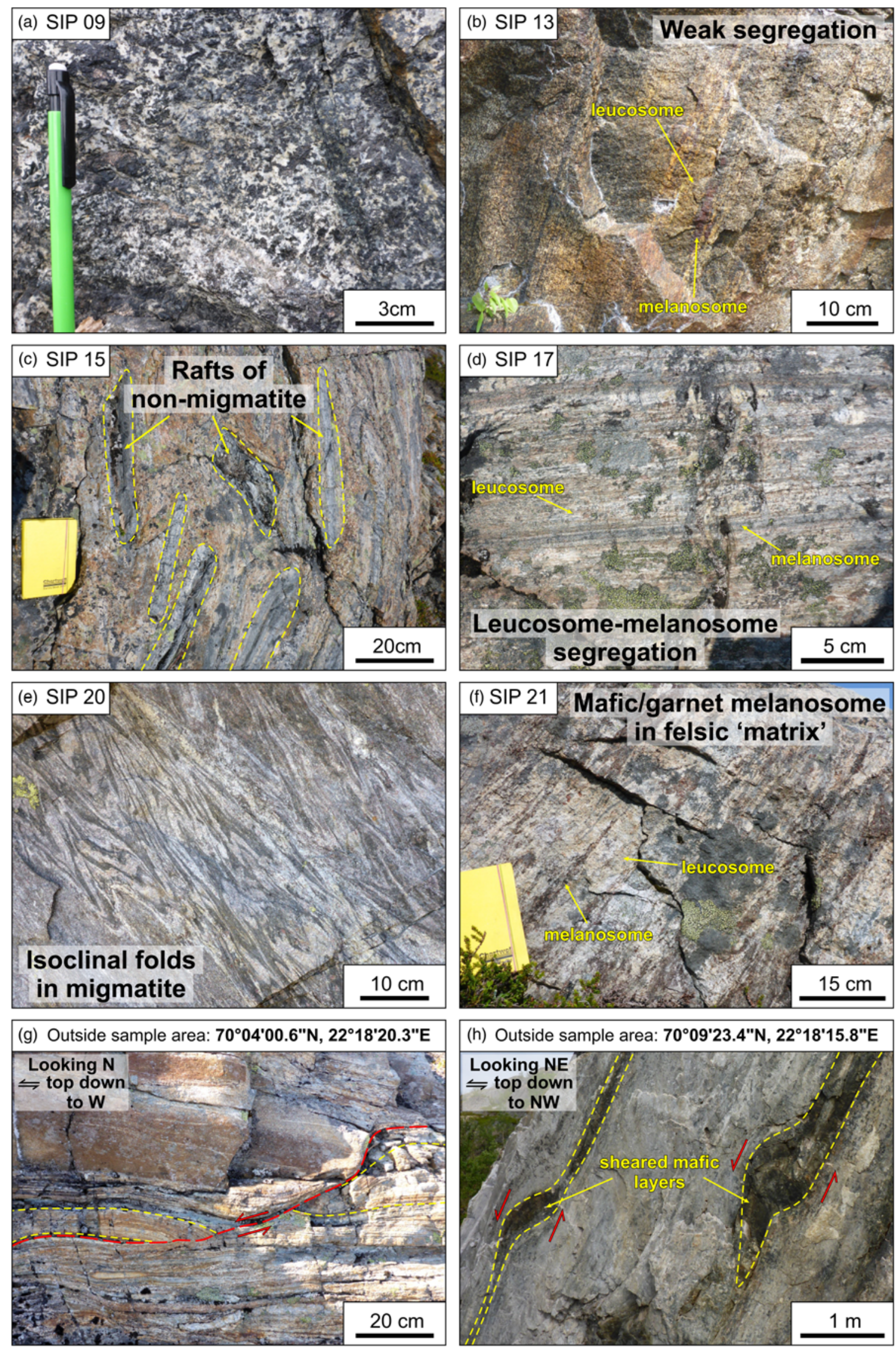

Fig. 2. Outcrop photographs from the ØSZ showing the transition from localized melt zones within gabbro to highly segregated stromatic migmatites with high-temperature mineral assemblages and internal deformation. (a) Gabbro outside the transition zone. (b) Transition zone paragneiss on edge of pod with weak leucosome-melanosome segregation. (c) Schollen-type migmatite near the shear zone boundary; rafts of mesosome within predominantly leucosome. (d) Stromatic migmatized paragneiss. (e) Isoclinal folds in stromatic migmatized paragneiss. (f) Migmatized paragneiss with mafic, garnet melanosome layers within a leucocratic matrix. (g) Flanking structure with top-down-to-west shearing in paragneiss; outcrop is located outside sample area. (h) Top-down-to-NW sheared mafic bands in leucocratic paragneiss; outcrop is located outside sample area. 

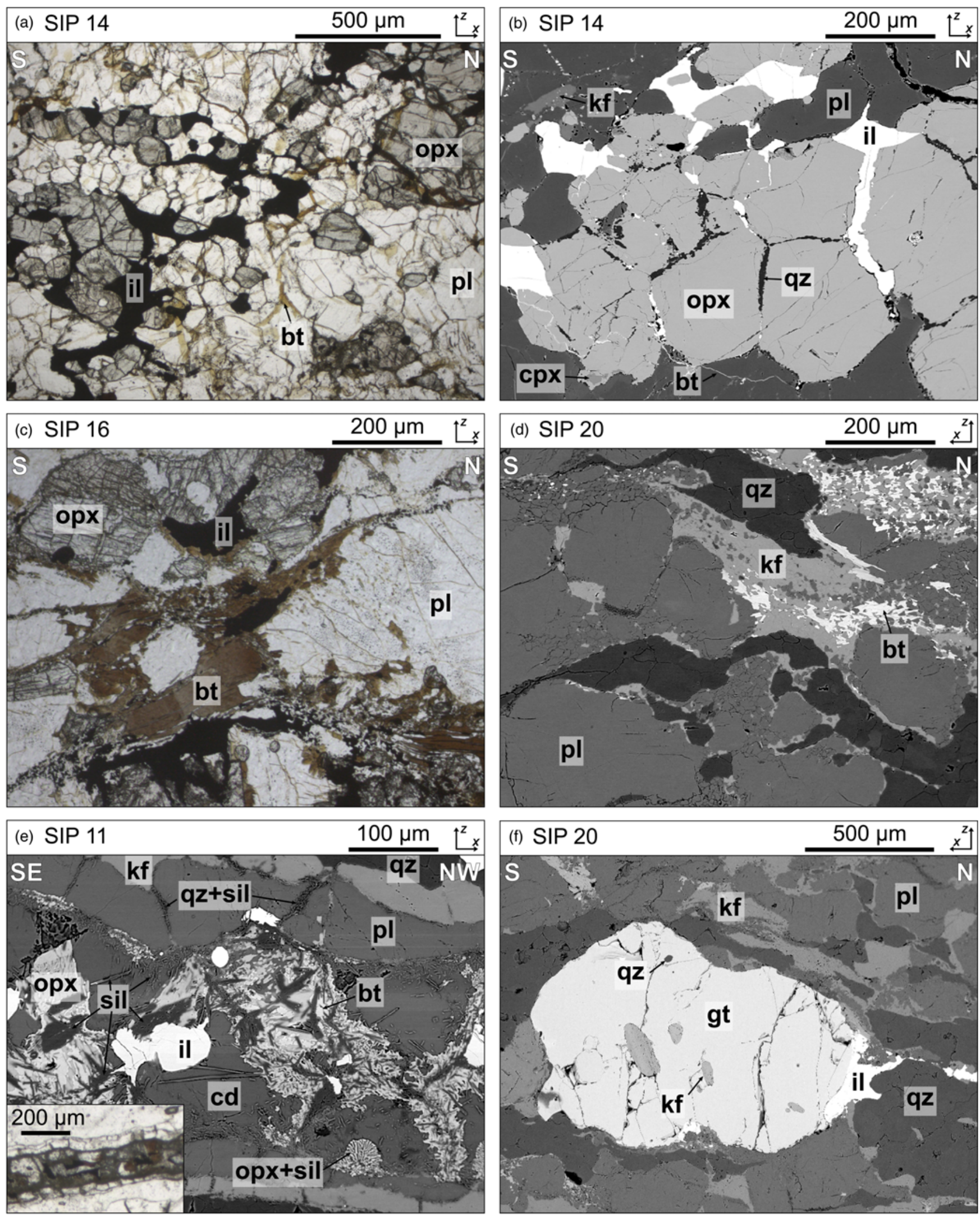

Fig. 3. Melt textures from the ØSZ from thin-section photomicrographs $(\mathbf{a}, \mathbf{c})$ and backscattered electron images $(\mathbf{b}, \mathbf{d}, \mathbf{e}, \mathbf{f})$. (a, b) Cuspate and interstitial ilmenite (il) representing former melt. (c, d) Biotite (bt) breakdown to K-feldspar (kf) and plagioclase (pl) forming melt at grain boundaries of quartz (qz) and plagioclase. (e) Melt zone within paragneiss raft, melt-rock interaction textures within isolated zones of the rock, orthopyroxene (opx) and cordierite (cd) is replaced by sillimanite (sil), biotite and ilmenite via back-reaction of melt. Inset photomicrograph shows an overview of the melt zone. (f) Large garnets (gt), with quartz and feldspar inclusions suggesting growth during subsolidus evolution of the migmatite. All micrographs viewed in $X Z$ plane of kinematic reference frame. 
observed where cordierite and orthopyroxene are replaced by biotite, sillimanite and ilmenite during retrogression and backreaction of the melt (Fig. 3e). Orthopyroxene is a major phase in samples located in the transition zone from gabbro to paragneiss; within the shear zone it is either not present or a minor phase. The lack of orthopyroxene within the paragneiss shear zone suggests that the transition area may be of a different composition and/or origin to the shear zone. Euhedral garnet grains, $200-500 \mu \mathrm{m}$ in size, are preserved in the centre of the ØSZ, suggesting that it is a peritectic product of biotite dehydration melting (SIP20, Fig. 3f).

The melt-solid-solid dihedral angle in the paragneiss ranges from $4^{\circ}$ to $85^{\circ}$ with a median of $26^{\circ}$, mean of $29^{\circ}$ and standard deviation of $17^{\circ}$ (method after Holness and Sawyer 2008; see supplementary material Fig. S1 for dihedral angle data). The solidsolid-solid dihedral angles from paragneisses are not in solid-state equilibrium as grain boundary dihedral angles vary from $49^{\circ}$ to $179^{\circ}$ with a median of $110^{\circ}$, mean of $109^{\circ}$ and standard deviation of $31^{\circ}$. The large range of dihedral angles is the result of deformation microstructures forming sutured grain boundaries.

\section{Melt volume analysis}

When considering the rheology and effect of strain localization in melt-present systems, it is important to understand the palaeomelt volume. At the field and outcrop scale the felsic portions of the rock are used to determine the leucosome content. The macroscale leucosome content is determined via image analysis of outcrop photographs (ImageJ; Schneider et al. 2012). Photographs were simplified with filters to correct for shadows, cracks or vegetation on the outcrop, helping to constrain leucosome versus restite proportions. Examples of the digitized outcrop drawings are shown in Figure 4a with the leucosome volumes from the ØSZ transect shown in Figure 4c. The leucosome content in the Øksfjord area varies from 0 to $50 \%$. However, this does not mean that up to $50 \%$ of the crust was melt, as the leucosome fraction does not necessarily equal the melt fraction.

It is necessary to use microstructures to distinguish if the leucosome formed from melting or solid-state deformation and recrystallization processes (Fig. 4b). Microscale melt determination is qualitative as we use microstructures indicative of melt or the former presence of melt (Figs 3 and $4 \mathrm{~b}$ ). With the use of ImageJ we isolate the melt and solid fractions of the rock. Plane-polarized light and cross-polarized light photomicrographs with and without gypsum plate are used to construct the melt-solid interpretations. Crystallized melt volume is calculated from microstructural and image analysis (Fig. 4c). The quantification is for the melt textures that remain in the microstructure; therefore, it could be an underestimate if significant melt loss or escape has occurred or an overestimate if melt crystallized in the shear zone during multiple melt fluxes.

The total melt volume in Figure 4d is calculated by attributing the micro-melt volume to the leucosome portion of the rock. For example, SIP20 has $15 \%$ melt in its microstructure and $38 \%$ leucosome at outcrop; this results in a $5.7 \%$ total melt volume as only $15 \%$ of the leucosome is composed of melt. Preserved melt textures suggest a peak crystallized melt volume for SIP20 of $<6 \%$, and $2-5 \%$ for nearby samples SIP18, 19, 21 and 22 . Towards the edges of the paragneiss melt textures are poorly preserved, where $<1 \%$ crystallized melt is observed for samples SIP16, 17, 24 and 43. (a)

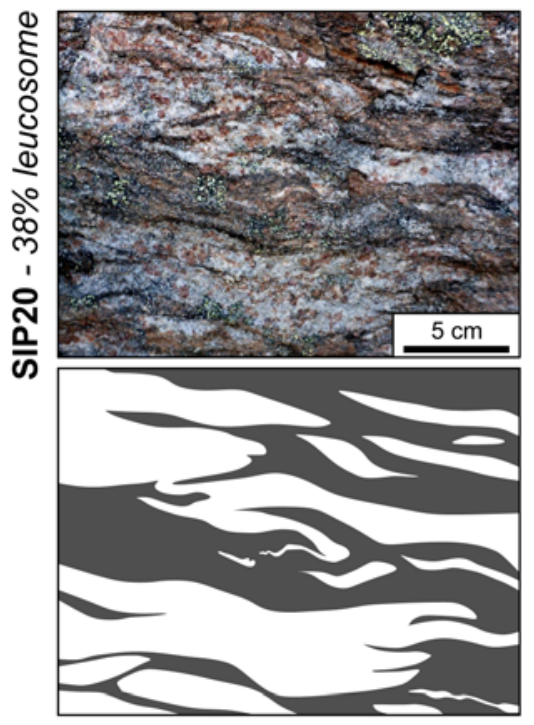

(c)

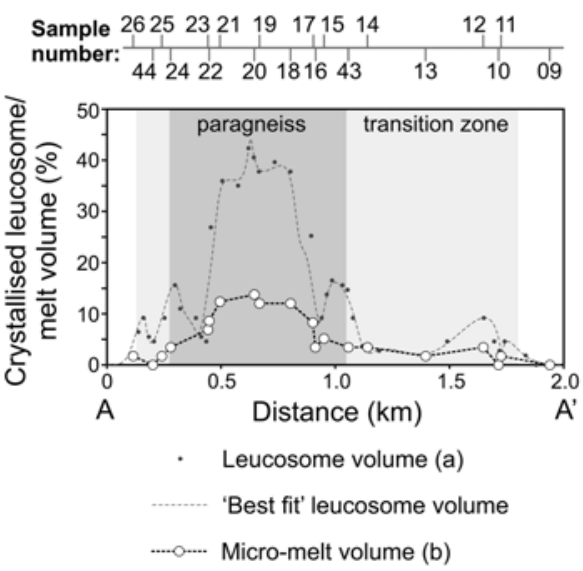

(b)

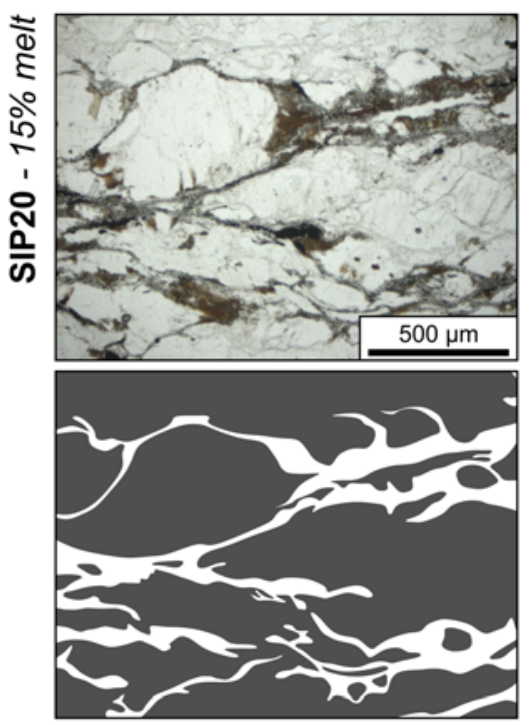

(d)
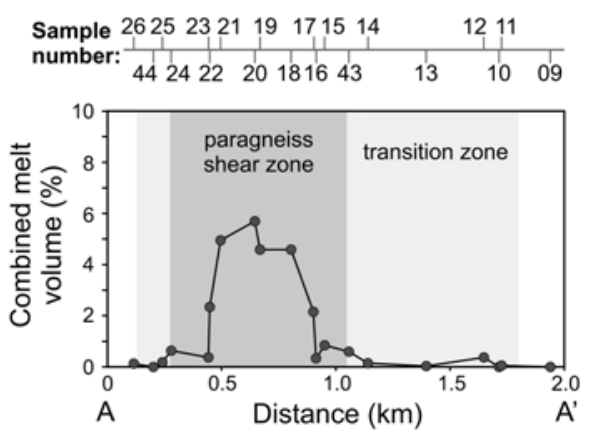

$\rightarrow$ Total melt volume
Fig. 4. Image analysis of field and microstructures to calculate leucosome and crystallized melt volume.

(a) Leucosome (white) v. restite (grey) image analysis interpretation of an example field photograph of SIP20 and (b) melt (white) v. solid (grey) image analysis interpretation of photomicrograph of SIP20. Plots of (c) field leucosome and microscale crystallized melt volume across the ØSZ and (d) total melt volume when the leucosome and micro-melt volumes are combined. 


\section{Deformation microstructures}

Quartz is not a major product of melt within the shear zone (e.g. Fig. $3 c-e)$, therefore it is inferred that quartz may preserve a pre-melt deformation history from the ØSZ. During melting, strain localizes into the melt, but if shearing is also active after crystallization, the peritectic phases may show evidence of deformation and melt textures may be destroyed.

In the centre of the shear zone, quartz is present as large grains with grain boundaries in disequilibrium (Fig. 5a and b). It is typical to observe chessboard subgrain extinction in large quartz grains $(>800 \mu \mathrm{m}$; Fig. $5 \mathrm{~b}$ ), often accompanied by an undulose extinction overprint. Where the grain size is smaller $(50-200 \mu \mathrm{m}$; Fig. 5a and b), quartz exhibits a lobate microstructure with serrated grain boundaries typical of grain boundary migration (GBM) microstructures. Here, rapid grain boundary mobility is favoured by high temperatures, sweeping through grains and removing dislocations (Guillope and Poirier 1979; Urai et al. 1986; Hirth and Tullis 1992; Stipp et al. 2002). Figure 5a shows a central band where there is evidence for melt reactions in the pressure shadows of plagioclase. This 'melt zone' is cutting quartz zones exhibiting GBM-type recrystallization. The quartz-plagioclase grain boundaries are straight and preservation of melt next to deformation microstructures suggests that the GBM quartz deformation predates melting.

Grain size decreases towards the shear zone boundaries; for quartz, the grain size ranges from 50 to $200 \mu \mathrm{m}$ in the centre and decreases to $10-80 \mu \mathrm{m}$ at the edges. Here, quartz grains have broken down to subgrains and dynamically recrystallized neoblasts, characteristic of subgrain rotation (SGR) recrystallization where additional dislocations allow the rotation of subgrains to develop new grains (Fig. 5c and d; Hirth and Tullis 1992; Stipp et al. 2002). Figure 5a shows evidence of a non-deformation textural relationship between melt and the deformed quartz; in contrast, Figure $5 \mathrm{~d}$ and e shows that the melt-consuming reaction phases (fine-grained biotite and K-feldspar) have been sheared and entrained during the formation of the SGR quartz ribbons and shearing of larger sigmoidal K-feldspar clasts. Large K-feldspar grains in these samples are winged mantled $\sigma$-type clasts with a sinistral, top-downto-the-west, sense of shear. If the migmatite was in equilibrium during crystallization, peritectic phases and delicate melt textures would be preserved; these features are not visible in shear zone boundary samples, suggesting post-melt deformation.

Garnet grains towards the edges of the paragneiss are 50-200 $\mu \mathrm{m}$ with irregular grain shapes. They are breaking down to quartz, K-feldspar, plagioclase and biotite, showing evidence of retrogression (Fig. 5f). Deformation at the edges of the paragneiss is likely to have occurred post-melting as melt microstructures are not preserved and peritectic phases are deformed.

\section{Crystallographic preferred orientations}

The crystallographic preferred orientations (CPOs) for quartzbearing samples within the ØSZ were analysed using the FEI Quanta 650 FEGSEM equipped with AZtec software and an Oxford/HKL Nordlys S EBSD system at the University of Leeds. All samples were run with a $20 \mathrm{kV}$ accelerating voltage, $5 \mu \mathrm{m}$ spot size and $5 \mu \mathrm{m}$ step size; the maximum step size is constrained by the minimum grain size $(20 \mu \mathrm{m})$; using the same step size ensures consistency when calculating grain and subgrain relationships.

Figure 6 shows the quartz pole figures for 11 samples from within the ØSZ. Samples SIP20 and 19 in the centre of the ØSZ have [c] maxima parallel to the $Y$ direction, compatible with prism $\langle a\rangle$ slip in quartz (e.g. Law et al. 1990). Samples SIP24, 22, 17, 16, and 43 located near the boundaries of the ØSZ show similar CPOs with an $X-Y$ girdle in $\langle a\rangle$ and a maximum at $Z$ in $[c]$. There is a slight asymmetry, especially in SIP17 where the [c] maxima suggests a sinistral shear component, compatible with field evidence. The CPO in these samples suggests deformation by basal $\langle a\rangle$ slip (e.g. Law et al. 1990). Samples between edges and centre of the ØSZ (SIP23, $21,18)$ have weak CPOs with diffuse poles at $Z$ in $[c]$. When the weak CPO is considered against their geographical position in the $\varnothing \mathrm{SZ}$, it is suggested that the crystal fabric represents an evolution through fabric overprinting from prism $\langle a\rangle$ slip in the centre and basal $\langle a\rangle$ slip at the edges (especially samples SIP21 and 18). SIP15, located at the edge of the ØSZ, is anomalous and does not have a maximum at $Z$ in $[c]$. This sample has large quartz grains with chessboard extinction and GBM in the smaller grains; the CPO is weak with basal $\langle a\rangle$ slip overprinting prism $\langle a\rangle$ slip.

\section{Stress and strain rate estimates}

Deformation mechanisms and CPO analysis provide qualitative data for stress and strain, whereas palaeopiezometry allows quantification of differential stress from grain size (e.g. Twiss 1977; Ord and Christie 1984; Stipp and Tullis 2003; Cross et al. 2017). It is possible therefore to estimate strain rate via flow laws (e.g. Luan and Paterson 1992; Gleason and Tullis 1995; Hirth et al. 2001). Generally, the smaller the recrystallized grain size, the higher the differential stress. However, in a melt-present system, grains crystallizing from the melt are typically larger than grains of the same mineral deformed in solid state. Thus, palaeopiezometers can only be used to quantify deformation post-melting. The results shown here give the relative change in magnitude of stress and strain rate across the ØSZ.

The centre of the shear zone has the highest palaeomelt content, which is problematic for calculation of stress from grain size. At the edges of the shear zone, our interpretation is that SGR deformation and basal $\langle a\rangle$ slip were active post-crystallization. It is appropriate therefore to apply a palaeopiezometer here. The recrystallized grain size is calculated from EBSD data via the grain orientation spread technique after Cross et al. (2017), whereby recrystallized and relict grains are isolated to find the recrystallized grain size (Fig. 7). The Cross et al. (2017) piezometer relationship is applied to calculate the differential stress $\left(\sigma_{1-3}\right)$ from recrystallized grain size $(D)$ for quartz-bearing samples in the ØSZ,

$$
D=10^{3.91 \pm 0.51} \sigma_{1-3}^{-1.41 \pm 0.21}
$$

Figure 7 shows the variation in recrystallized grain size across the ØSZ. The grain size relationship loosely follows the melt volume trend; both increase towards the centre of the shear zone (e.g. root mean squared (r.m.s.) recrystallized grain size in the centre is $48.2 \pm 7.6 \mu \mathrm{m}$, SIP20, 19 , and drops to $21.6 \pm 10.2 \mu \mathrm{m}$ at the edges, SIP24, 17, 16, 43). The grain size relationship corresponds to samples where GBM is dominant (large, centre) and samples where SGR is active (small, edges).

The palaeopiezometer is applied to the r.m.s. recrystallized grain sizes to calculate the differential stresses (Fig. 7). The differential stress in the centre of the shear zone is $38 \pm 4.3 \mathrm{MPa}$ (SIP20, 19), increases to $44 \pm 11.5 \mathrm{MPa}$ with the evolving quartz fabric (transition from prism $\langle a\rangle$ to basal $\langle a\rangle$ slip; SIP23, 21, 18, 15) and further increases to $68 \pm 17 \mathrm{MPa}$ for the shear zone edges (SIP24, 17, 16, 43). The differential stress variation within the shear zone therefore suggests faster strain rates at the edges of the shear zone and slower strain rates in the centre.

The rheological behaviour of rocks is expressed through flow laws, which describe the dependence of strain rate on parameters such as stress and temperature (Poirier 1985; Hirth et al. 2001). In this paper we apply the quartz power-law flow law for dislocation creep (Tokle et al. 2019) to understand any relative changes in 

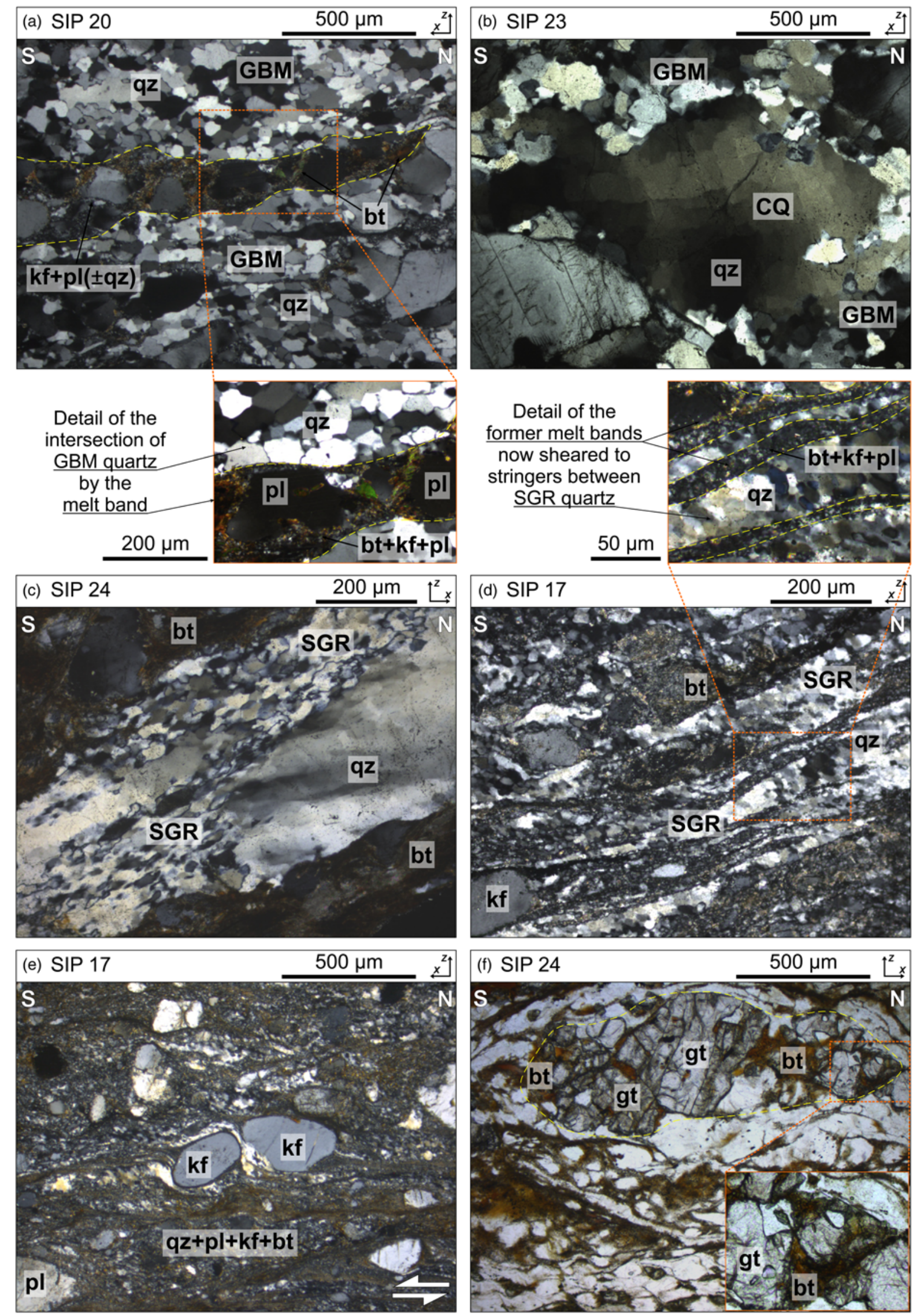

Fig. 5. Thin-section photomicrographs of deformation microstructures from the ØSZ. (a) Lobate-serrated grain boundaries of quartz recrystallizing by GBM cut by a K-feldspar, plagioclase and biotite melt band highlighted in yellow. (b) Large quartz grain showing chessboard extinction (CQ) with an undulose extinction overprint; smaller grains at edge recrystallized by GBM. (c) Large quartz grain recrystallizing by SGR. (d) Recrystallization of quartz ribbons and grains by SGR. (e) Sigmoidal feldspar clasts with sinistral sense of shear. (f) Retrogressed garnet breaking down to quartz, feldspars and biotite. All micrographs viewed in $X Z$ plane of kinematic reference frame. 


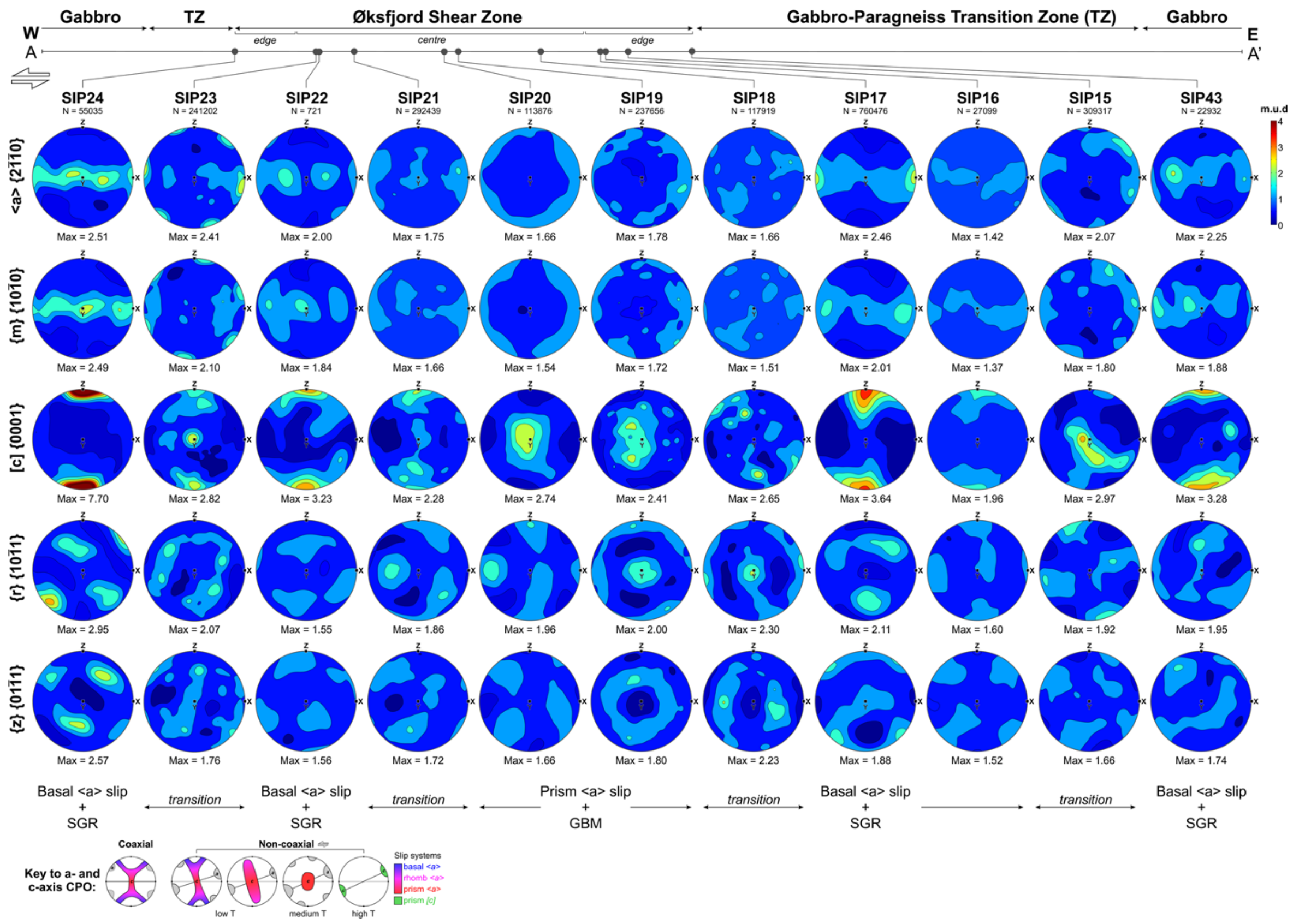

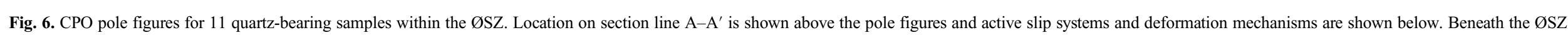
$\mathrm{CPO}$ is a key to the $a$ - and $c$-axis CPO development and active $\langle a\rangle$ slip systems showing temperature-dependent CPO development of (grey) and [c] (coloured maxima) during coaxial and non-coaxial dextral shearing (modified from Passchier and Trouw 2005; Parsons et al. 2016). 

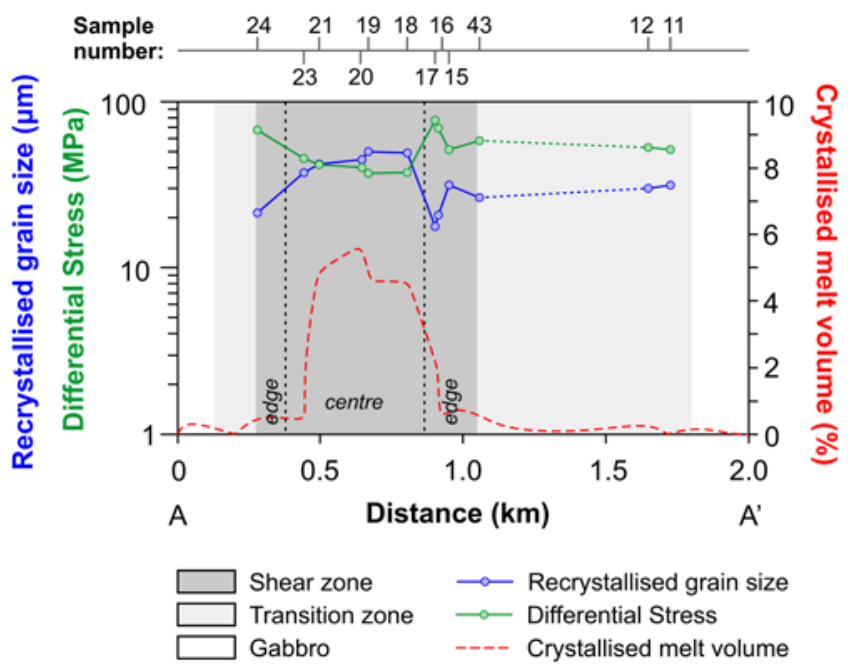

Fig. 7. Recrystallized grain size and palaeopiezometer for quartz-bearing samples from the ØSZ. Recrystallized grain size (blue) calculated from EBSD data using GOS; palaeopiezometer (green) relationship after Cross et al. (2017); melt volume (red) calculated from melt v. solid image analysis interpretations of outcrops and photomicrographs.

magnitude of strain rate:

$$
\begin{gathered}
\dot{\varepsilon}=A \sigma_{1-3}^{n} f_{\mathrm{H}_{2} \mathrm{O}}^{r} \mathrm{e}^{-Q / R T} \\
\dot{\varepsilon}=\dot{\varepsilon}_{\mathrm{disGBS}}+\dot{\varepsilon}_{\mathrm{disl}}
\end{gathered}
$$

where $\dot{\varepsilon}$ is strain rate, $\sigma_{1-3}$ is differential stress, $n$ is the stress exponent, $f_{\mathrm{H}_{2} \mathrm{O}}$ is the water fugacity, $r$ is the water fugacity exponent, $Q$ is the activation enthalpy, $R$ is the ideal gas constant, $T$ is absolute temperature $\left(T=800^{\circ} \mathrm{C}\right.$ for centre samples and $T=700^{\circ} \mathrm{C}$ for edge samples), and $A$ is a material parameter. The flow law parameters for dislocation-accommodated grain boundary sliding (disGBS) with a power-law stress exponent of $n=4$ are $Q=125 \mathrm{~kJ} \mathrm{~mol}^{-1}, r=1$, $f_{\mathrm{H}_{2} \mathrm{O}}=200 \mathrm{MPa}$ and $A=1.75 \times 10^{-12} \mathrm{MPa}^{-n} \mathrm{~s}^{-1}$; and parameters for low-temperature-high-stress dislocation creep (disl) with a stress exponent of $n=3$ are $Q=115 \mathrm{~kJ} \mathrm{~mol}^{-1}, r=1.2, f_{\mathrm{H}_{2} \mathrm{O}}=50 \mathrm{MPa}$ and $A=1.1 \times 10^{-12} \mathrm{MPa}^{-n} \mathrm{~s}^{-1}$, where the final strain rate is the sum of the dislocation-accommodated grain boundary sliding component and the dislocation creep component (equation (3)). If the quartz power-law flow law for dislocation creep is applied to the calculated stresses, it yields strain rates of $4.6 \times 10^{-12}, 3.8 \times 10^{-12}$ and $2.9 \times 10^{-11}$ for the ØSZ centre, transitioning fabric and edges respectively. Although these estimates do not represent the true deformation conditions of the ØSZ, they do indicate that the shear zone edges deformed at an order of magnitude faster strain rate than the shear zone centre during post-crystallization deformation.

\section{Discussion}

The ØSZ is a high-strain deformation zone of migmatized paragneiss. Outside the shear zone there is a transition to foliated gabbro with pockets of paragneiss to foliated gabbro with no evidence for partial melting. The ØSZ is part of a series of thin ductile paragneiss shear zones within the gabbro that formed by syn-intrusive deep crustal shearing during lithospheric extension (Elvevold et al. 1994; Roberts et al. 2006a). The paragneiss is strongly sheared and kinematic indicators suggest oblique sinistralnormal faulting, supporting the extensional rifting model for the Seiland Igneous Province (Reginiussen et al. 1995). However, a sinistral shear sense is contradictory to the NW-plunging stretching lineation. The lineation is sparse with a sample size of eight; alternatively it may represent an early deformation phase of the Eidvågeid sequence that was overprinted during the formation of the ØSZ. The rafts of paragneiss were probably entrained within the gabbro during intrusion; they are richer in orthopyroxene than samples in the main shear zone, suggesting metamorphic and melt reactions with the gabbro.

\section{Interpretation of OSZ shear zone evolution}

Typically palaeo shear zones have a grain size distribution of coarse grains at the edges and fine grains in the centre where the strain was higher (Ramsay and Graham 1970; White 1979; Olgaard and Evans 1988). In the ØSZ the reverse is the case, with large grains in the centre and small grains at the edges (Fig. 7). The normal grain size distribution is observed only in melt-free areas. The slip systems and deformation mechanisms responsible for the recorded CPOs and microstructure in the ØSZ are likely to have been active at different times as variation of deformation conditions (e.g. temperature and stress) over the narrow shear zone is unlikely.

The deformation phase that formed the GBM-type fabric preserved in the centre of the ØSZ is likely to have occurred premelting. During prograde metamorphism prior to partial melting, quartz deformed by GBM and prism $\langle a\rangle$ slip, and large quartz grains formed chessboard subgrains (Fig. 8a). Experiments suggest that GBM and prism $\langle a\rangle$ slip is favoured by high temperature and mid- to low-stress deformation (Nachlas and Hirth 2015; Richter et al. 2016).

The inverse grain size distribution in the ØSZ is probably the result of the influence of melt in the system. Grain growth is promoted at high temperatures and during transport of melt through the system, which can occur in a number of ways: static recrystallization outpacing dynamic recrystallization (Evans et al. 2001), crystallization of grains directly from melt where crystallization rate outpaces strain rate (Jurewicz and Watson 1985), or diffusion through the melt phase. In the ØSZ it is likely that all processes were active, resulting in grain growth of solid and peritectic phases. Melt microstructures in samples from the centre of the shear zone are well preserved with little deformation observed in the peritectic melt phases (Figs 5a and 8a). The melt textures present indicate up to $6 \%$ of crystallized melt in the centre of the system, decreasing in volume through to the edges of the ØSZ and within the transition zone. The low melt-solid-solid dihedral angles and grain boundary melt films suggest that melt connectivity was high in the paragneiss. Melt would have been able to move through the shear zone but the crystallized remnants of melt suggest that there was pooling and crystallization when it was unable to escape the system. Higher melt volumes than preserved today may have initially been present at the shear zone edges but may have been transported to the centre and evidence of melt textures has been deformed. Grain growth is greater in the centre of the ØSZ as a result of the enhanced in situ crystallized melt presence here.

Menegon et al. (2011) suggested that 5-7\% melt was located in isolated pockets and did not control the mechanical strength of the ØSZ. However, in the shear zone samples studied here, located $c$. $10 \mathrm{~km}$ south of those sampled by Menegon et al. (2011), melt has low dihedral angles and forms grain boundary melt films forming an interconnected melt framework. Interconnected melt networks result in mechanical weakening during melting; the 5-7\% melt present in the ØSZ is sufficient to cause a dramatic strength decrease and thus controls the mechanical strength of the shear zone (Fig. 8b; Rosenberg and Handy 2005; Llorens et al. 2019). Degli Alessandrini et al. (2017) analysed dry mafic dykes from the same area as Menegon et al. (2011) and suggested that melt-induced chemical reactions may be a common feature in the lower crust and responsible for weakening the dry, strong mafic rocks. As a result, melt-assisted deformation in the lower crust is likely to have a dramatic effect on the strength of dry, strong mafic rocks. Partial melting in the $Ø \mathrm{SZ}$ occurred at high temperatures $\left(760-820^{\circ} \mathrm{C}\right.$; Menegon et al. 2011), and during this evolution phase stress was 

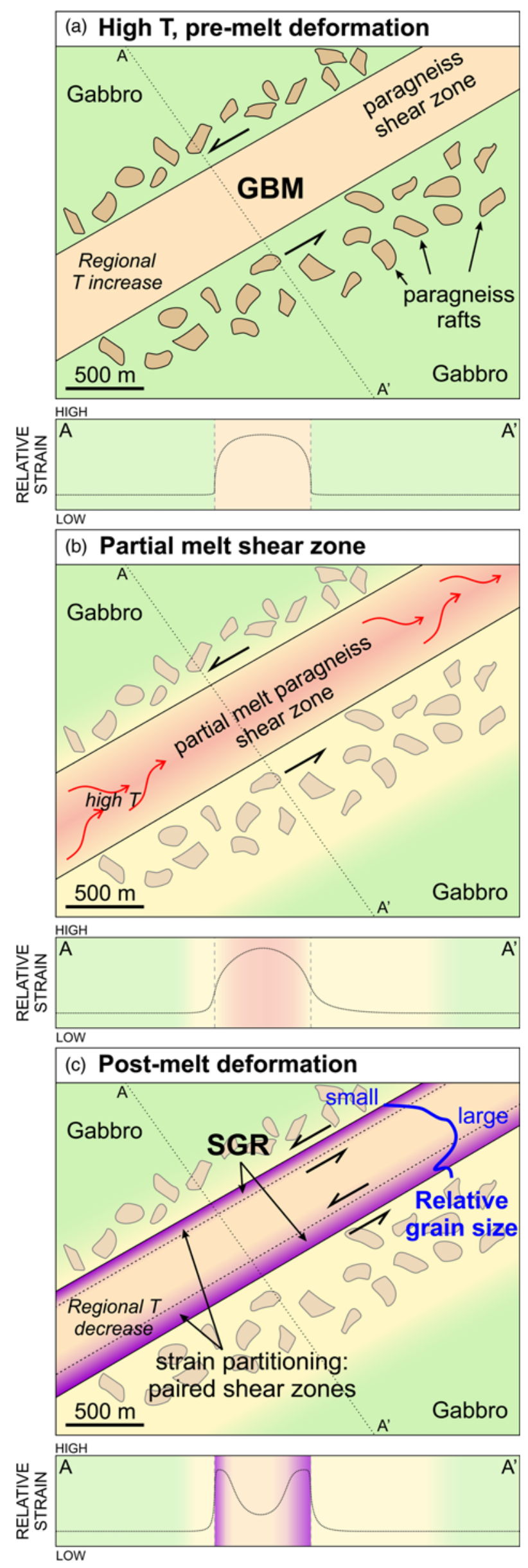

Fig. 8. Continued
Fig. 8. Schematic diagrams of pre-, syn- and post-melt evolution of the ØSZ; relative strain rate is shown schematically beneath each diagram. (a) Post-gabbro intrusion and pre-melting of the ØSZ; deformation at high temperatures by GBM after intrusion of gabbro into the gneiss. Paragneiss rafts were entrained into gabbro during intrusion. Relative strain: higher inside the shear zone than in the gabbro. (b) Syn-melt deformation in the ØSZ; higher melt volume towards shear zone centre promotes a grain size increase in crystallization of peritectic phases; at this stage solid phases do not deform as melt localizes the strain. Relative strain: high in centre, low at edges. (c) Crystallization of shear zone and post-melt deformation; upon regional temperature decrease the shear zone crystallizes forming a 'strong' centre; pre-melt GBM deformation and melt-induced grain growth produces a grain size distribution from small to large from edges to centre. Post-melt deformation results in a partitioning of strain to shear zone edges where grain size is smaller; the deformation forms a set of paired shear zones deforming by SGR at lower temperature and higher stress, overprinting evidence for melting at shear zone edges. Relative strain: low in centre, high at edges.

absorbed by the melt (Fig. 8b). Percolation of partial melt through the shear zone resulted in an overprinting of the GBM deformation microstructure by melt textures (Fig. 8b).

At the edges of the ØSZ, the quartz grain size is smaller. It was reduced during SGR-type deformation with basal $\langle a\rangle$ slip as the active slip system. When this grain size reduction is considered alongside deformed feldspar grains, lack of quartz grains with chessboard extinction, entrained former melt zones alongside quartz ribbons and lack of peritectic garnet, it supports our contention that the edges of the ØSZ deformed post-melting at higher stresses and lower temperatures (Figs $5 \mathrm{c}-\mathrm{e}$ and $8 \mathrm{c}$ ). This later deformation phase nucleated two parallel shear zones at the edges of the larger ØSZ. The foliation and lineation data are consistent throughout the ØSZ, suggesting that the post-melt deformation of the shear zone by SGR and basal $\langle a\rangle$ slip is a later part of the same deformation event. The undulose extinction overprint of chessboard extinction grains in the shear zone centre suggests minor retrograde deformation at lower temperatures (Fig. 5b).

We propose that the slip systems and deformation mechanisms responsible for the recorded CPOs and microstructure in the ØSZ are likely to have been active at different times as a steep temperature gradient over the narrow shear zone is unlikely. This is supported by evidence of deformation microstructures overprinting melt microstructures at the edges of the ØSZ (Figs 5a,d and 8c), suggesting that the edges deformed later than the centre.

\section{Paired shear zones as larger crustal features}

Post-melt deformation at the shear zone edges, localizing on the boundary with the rigid gabbro, is a similar structure to paired shear zones observed at the millimetre to centimetre scale in ductile midto lower crust, such as in the Neves area, Eastern Alps (Mancktelow and Pennacchioni 2005; Pennacchioni and Mancktelow 2007, 2018) and in Fiordland, New Zealand (Smith et al. 2015). The central syn-melt deformation zone of the ØSZ is $500 \mathrm{~m}$ wide with $100-150 \mathrm{~m}$ wide post-melt shear zones flanking the partial melt shear zone. The ØSZ is 4-5 orders of magnitude wider than shear zones observed by Mancktelow and Pennacchioni (2005), Pennacchioni and Mancktelow $(2007,2018)$ and Smith et al. (2015). We suggest that the ØSZ is a large-scale manifestation of the same mechanisms where paired shear zones flank millimetre- to centimetre-scale strong heterogeneities in the rock. During syn-melt deformation, strain localized towards the centre of the ØSZ where the melt fraction was highest. Upon crystallization and formation of the paired shear zones flanking the former syn-melt shear zone, strain partitioned to the edges. 


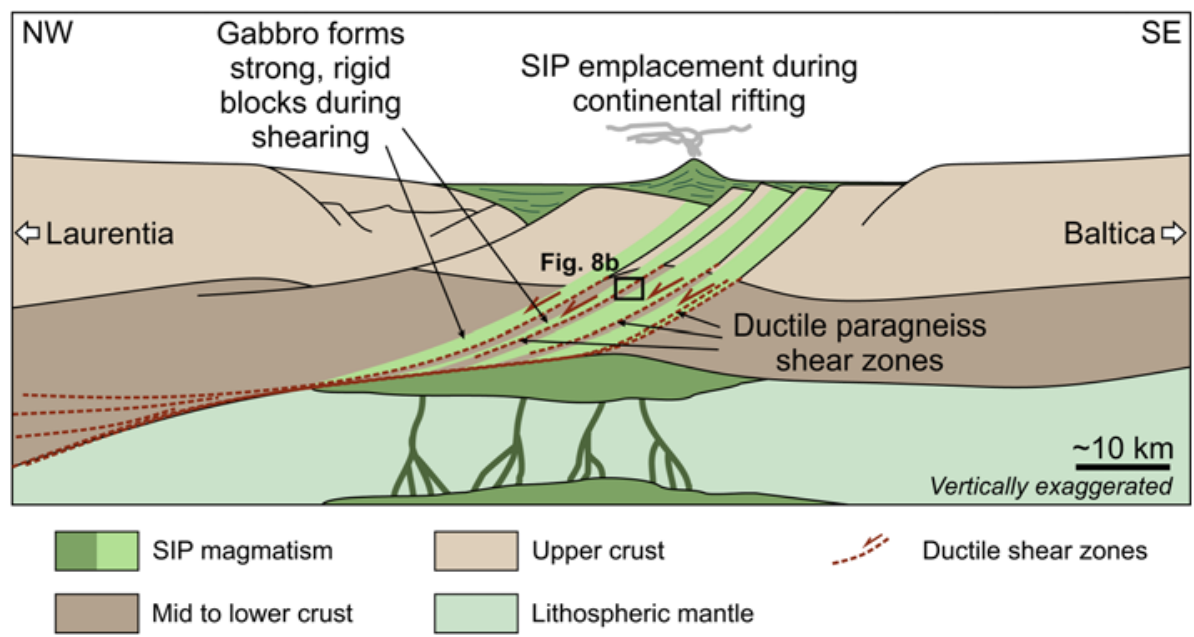

Fig. 9. Schematic tectonic model for Seiland Igneous Province emplacement and shear zone development adapted from models by Clerc et al. (2015), Abdelmalak et al. (2017) and Kjøll et al. (2019).

The Seiland Igneous Province represents a former rift zone where the paragneiss shear zones formed during syn-intrusive deep crustal shearing (Elvevold et al. 1994; Roberts et al. 2006a). Evidence for this type of shear zone has been observed in present-day rifted margins (e.g. Atlantic rifting; Clerc et al. 2015, 2018) as well as older, former Iapetus margins (e.g. Kjøll et al. 2019). Seiland Igneous Province emplacement alongside the shear zones suggests that the Seiland Igneous Province was part of a magma-rich continental rift zone where the paragneiss formed ductile mid-crustal shear zones as illustrated in Figure 9. When this tectonic model is combined with $\mathrm{U}-\mathrm{Pb}$ age data for intrusive bodies adjacent to Øksfjorden (c. $565 \mathrm{Ma}$ after Roberts et al. 2006a) and the microstructural analysis from this study, it indicates that partial melting in the ØSZ occurred syn-emplacement of the Seiland Igneous Province gabbro but was short-lived, and deformation continued post-melt to accommodate extension on the Baltica margin.

\section{Conclusions}

Coexistence of deformation and melt microstructures suggests a complex geological history for the ØSZ. In contrast to conventional expectations for melt-free shear zones, a reverse grain size distribution is observed with finer grains at the shear zone edges and coarser grains in the centre. In addition, high-temperature, low-stress deformation microstructures (GBM, prism $\langle a\rangle$ slip) are recognized in the shear zone centre, with mid-temperature, highstress deformation microstructures (SGR, basal $\langle a\rangle$ slip) at the shear zone edges.

We argue that strain localized towards the centre of the shear zone during a regional temperature increase, which ultimately led to partial melting. During the pre-melt phase, the shear zone deformed at high temperatures, resulting in grain growth from GBM deformation. During partial melting, melt localized strain during this time and absorbed the majority of the stress. The percolation of melt and formation of melt textures dissect the pre-melt deformation and overprint some of these microstructures. The high temperatures and crystallization from partial melt promoted further grain growth of already relatively coarse-grained residual phases in the shear zone. Once all the melt had crystallized and/or escaped from the system and the temperature decreased, the centre of the shear zone was 'strong' relative to leucosome-poor margins. As the temperature decreased further, and the stress absorbed by the solid phases increased, the leucosome-poor margins proved easier to deform and hence strain partitioned to the shear zone boundaries, forming the paired shear zones observed today. Unlike partial melt shear zones where melt organization and pinning of new grain growth promotes grain size reduction, grain growth during crystallization of the ØSZ centre transferred stress to shear zone edges to permit continued deformation and extension of the Baltica margin, suggesting that syn-melt shear zones form significant heterogeneities that continue to reduce the strength of the crust upon crystallization.

Acknowledgements A.L.L. would like to thank A. Parsons for field assistance in the Seiland Igneous Province. The authors thank L. Menegon and E. Sawyer for their reviews, and D. Gasser for additional reviews and editorial handling; all comments greatly improved the quality of this paper.

Funding This work was funded by the Geological Society of London (Timothy Jefferson Field Research Fund (2015)) and the Natural Environment Research Council (NE/K008803/1 and NE/M000044/1).

Author contributions ALL: conceptualization (lead), data curation (lead), formal analysis (lead), funding acquisition (lead), investigation (lead), methodology (lead), project administration (lead), resources (lead), software (lead), visualization (lead), writing - original draft (lead), writing - review \& editing (lead); GEL: supervision (equal), writing - review \& editing (supporting); TT: supervision (supporting), writing - review \& editing (supporting); AMW: supervision (equal), writing - review \& editing (equal).

\section{Scientific editing by Deta Gasser}

\section{References}

Abdelmalak, M.M., Faleide, J.I., Planke, S., Gernigon, L., Zastrozhnov, D., Shephard, G.E. and Myklebust, R. 2017. The T-reflection and the deep crustal structure of the Vøring margin, offshore mid-Norway. Tectonics, 36, 2497-2523, https://doi.org/10.1002/2017TC004617

Akselsen, J. 1982. Precambrian and Caledonian tectonometamorphic evolution of northeastern Seiland, Finnmark, North Norway. Norges Geologiske Undersøkelse Bulletin, 373, 45-61.

Austrheim, H. and Boundy, T.M. 1994. Pseudotachylytes generated during seismic faulting and eclogitization of the deep crust. Science, 265, 82-83, https://doi.org/10.1126/science.265.5168.82

Brown, M. 2001. Orogeny, migmatites and leucogranites: a review. Journal of Earth System Science, 110, 313-336, https://doi.org/10.1007/BF02702898

Brown, M., Averkin, Y.A., McLellan, E.L. and Sawyer, E.W. 1995. Melt segregation in migmatites. Journal of Geophysical Research: Solid Earth, 100, 15655-15679, https://doi.org/10.1029/95JB00517

Clerc, C., Jolivet, L. and Ringenbach, J.-C. 2015. Ductile extensional shear zones in the lower crust of a passive margin. Earth and Planetary Science Letters, 431, 1-7, https://doi.org/10.1016/j.epsl.2015.08.038

Clerc, C., Ringenbach, J.-C., Jolivet, L. and Ballard, J.-F. 2018. Rifted margins: ductile deformation, boudinage, continentward-dipping normal faults and the role of the weak lower crust. Gondwana Research, 53, 20-40, https://doi.org/ 10.1016/j.gr.2017.04.030

Corfu, F., Torsvik, T.H., Anderson, T.B., Ashwal, L.D., Ramsay, D.M. and Roberts, R.J. 2006. Early Silurian mafic-ultramafic and granitic plutonism in contemporaneous flysch, Magerø, northern Norway: $\mathrm{U}-\mathrm{Pb}$ ages and regional significance. Journal of the Geological Society, London, 163, 291-301, https://doi.org/10.1144/0016-764905-014

Corfu, F., Roberts, R.J., Torsvik, T.H., Ashwal, L.D. and Ramsay, D.M. 2007. Peri-Gondwanan elements in the Caledonian Nappes of Finnmark, Northern Norway: implications for the paleogeographic framework of the Scandinavian Caledonides. American Journal of Science, 307, 434-458, https://doi.org/10. 2475/02.2007.05 
Corfu, F., Gerber, M., Andersen, T.B., Torsvik, T.H. and Ashwal, L.D. 2011. Age and significance of Grenvillian and Silurian orogenic events in the Finnmarkian Caledonides, northern Norway. Canadian Journal of Earth Sciences, 48, 419-440, https://doi.org/10.1139/E10-043

Cross, A.J., Prior, D.J., Stipp, M. and Kidder, S. 2017. The recrystallized grain size piezometer for quartz: an EBSD-based calibration. Geophysical Research Letters, 44, 6667-6674, https://doi.org/10.1002/2017GL073836

Degli Alessandrini, G., Menegon, L., Malaspina, N., Dijkstra, A.H. and Anderson, M.W. 2017. Creep of mafic dykes infiltrated by melt in the lower continental crust (Seiland Igneous Province, Norway). Lithos, 274-275, 169-187, https://doi.org/10.1016/j.lithos.2016.12.030

Elvevold, S., Reginiussen, H., Krogh, E.J. and Bjørklund, F. 1994. Reworking of deep-seated gabbros and associated contact metamorphism paragneisses in the southeastern part of the Seiland Igneous Province, northern Norway. Journal of Metamorphic Geology, 12, 539-556, https://doi.org/10.1111/j.1525-1314. 1994.tb00041.x

Evans, B., Renner, J. and Hirth, G. 2001. A few remarks on the kinetics of static grain growth in rocks. International Journal of Earth Sciences, 90, 88-103, https://oi.org/10.1007/s005310000150

Fossen, H. and Cavalcante, G.C.G. 2017. Shear zones: a review. Earth-Science Reviews, 171, 434-455, https://doi.org/10.1016/j.earscirev.2017.05.002

Gasser, D., Jeřábek, P., et al. 2015. Behaviour of geochronometers and timing of metamorphic reactions during deformation at lower crustal conditions: phase equilibrium modelling and $\mathrm{U}-\mathrm{Pb}$ dating of zircon, monazite, rutile and titanite from the Kalak Nappe Complex, northern Norway. Journal of Metamorphic Geology, 33, 513-534, https://doi.org/10.1111/jmg.12131

Gleason, G.C. and Tullis, J. 1995. A flow law for dislocation creep of quartz aggregates determined with the molten salt cell. Tectonophysics, 247, 1-23, https://doi.org/10.1016/0040-1951(95)00011-B

Guillope, M. and Poirier, J.-P. 1979. Dynamic recrystallisation during creep of single crystalline halite: an experimental study. Journal of Geophysical Research: Solid Earth, 84, 5557-5567, https://doi.org/10.1029/JB084iB10p05557

Hirth, G. and Tullis, J. 1992. Dislocation creep regimes in quartz aggregates. Journal of Structural Geology, 14, 145-159, https://doi.org/10.1016/01918141(92)90053-Y

Hirth, G., Teyssier, C. and Dunlap, W.J. 2001. An evaluation of quartzite flow laws based on comparisons between experimentally and naturally deformed rocks. International Journal of Earth Sciences, 90, 77-87, https://doi.org/10. 1007/s005310000152

Holness, M.B. and Sawyer, E.W. 2008. On the pseudomorphing of melt-filled pores during the crystallization of migmatites. Journal of Petrology, 49, 1343-1363, https://doi.org/10.1093/petrology/egn028

Hull, J. 1988. Thickness-displacement relationships for deformation zones. Journal of Structural Geology, 10, 431-435, https://doi.org/10.1016/01918141(88)90020-X

Jurewicz, S.R. and Watson, E.B. 1985. The distribution of partial melt in a granitic system: The application of liquid phase sintering theory. Geochimica et Cosmochimica Acta, 49, 1109-1121, https://doi.org/10.1016/0016-7037 (85)90002-X

Karato, S.-I. 2010. Rheology of the deep upper mantle and its implications for the preservation of the continental roots: a review. Tectonophysics, 481, 82-98, https://doi.org/10.1016/j.tecto.2009.04.011

Kirkland, C.L., Daly, J.S. and Whitehouse, M.J. 2006. Granitic magmatism of Grenvillian and late Neoproterozoic age in Finnmark, Arctic Norway constraining pre-Scandian deformation in the Kalak Nappe Complex. Precambrian Research, 145, 24-52, https://doi.org/10.1016/j.precamres. 2005.11.012

Kirkland, C.L., Daly, J.S., Eide, E.A. and Whitehouse, M.J. 2007a. Tectonic evolution of the Arctic Norwegian Caledonides from a texturally- and structurally-constrained multi-isotopic ( $\mathrm{Ar}-\mathrm{Ar}, \mathrm{Rb}-\mathrm{Sr}, \mathrm{Sm}-\mathrm{Nd}, \mathrm{U}-\mathrm{Pb})$ study. American Journal of Science, 307, 459-526, https://doi.org/10.2475/02 2007.06

Kirkland, C.L., Daly, J.S. and Whitehouse, M.J. 2007b. Provenance and terrane evolution of the Kalak Nappe Complex, Norwegian Caledonides: implications for Neoproterozoic paleogeography and tectonics. Journal of Geology, 115, 21-41, https://doi.org/10.1086/509247

Kirkland, C.L., Daly, J.S., Chew, D.M. and Page, L.M. 2008. The Finnmarkian Orogeny revisited: an isotopic investigation in eastern Finnmark, Arctic Norway. Tectonophysics, 460, 158-177, https://doi.org/10.1016/j.tecto.2008.08.001

Kjøll, H.J., Andersen, T.B., Corfu, F., Labrousse, L., Tegner, C., Abdelmalak, M.M. and Planke, S. 2019. Timing of break-up and thermal evolution of a preCaledonian Neoproterozoic exhumed magma-rich rifted margin. Tectonics, 38, 1843-1862, https://doi.org/10.1029/2018TC005375

Krogh, E.J. and Elvevold, S. 1990. A Precambrian age for an early gabbromonzonitic intrusive on the Øksfjord peninsula, Seiland Igneous Province, northern Norway. Norsk Geologisk Tidsskrift, 70, 267-273.

Labrousse, L., Jolivet, L., Andersen, T.B., Agard, P. and Maluski, H. 2004 Pressure-temperature-time deformation history of the exhumation of ultrahigh pressure rocks in the Western Gneiss Region, Norway. Geological Society of America, Special Papers, 380, 155-183, https://doi.org/10.1130/08137-2380-9.155

Law, R.D., Schmid, S.M. and Wheeler, J. 1990. Simple shear deformation and quartz crystallographic fabrics: a possible natural example from the Torridon area of NW Scotland. Journal of Structural Geology, 12, 29-45, https://doi. org/10.1016/0191-8141(90)90046-2
Lee, A.L., Walker, A.M., Lloyd, G.E. and Torvela, T. 2017. Modeling the impact of melt on seismic properties during mountain building. Geochemistry, Geophysics, Geosystems, 18, 1090-1110, https://doi.org/10.1002 2016GC006705

Lee, A.L., Torvela, T., Lloyd, G.E. and Walker, A.M. 2018. Melt organisation and strain partitioning in the lower crust. Journal of Structural Geology, 113, 188-199, https://doi.org/10.1016/j.jsg.2018.05.016

Llorens, M.-G., Gomez-Rivas, E., et al. 2019. The effect of dynamic recrystallisation on the rheology and microstructures of partially molten rocks. Journal of Structural Geology, 118, 224-235, https://doi.org/10.1016/j. jsg.2018.10.013

Luan, F.C. and Paterson, M.S. 1992. Preparation and deformation of synthetic aggregates of quartz. Journal of Geophysical Research: Solid Earth, 97, 301-320, https://doi.org/10.1029/91JB01748

Mancktelow, N.S. and Pennacchioni, G. 2005. The control of precursor brittle fracture and fluid-rock interaction on the development of single and paired ductile shear zones. Journal of Structural Geology, 27, 645-661, https://doi. org/10.1016/j.jsg.2004.12.001

Means, W.D. 1995. Shear zones and rock history. Tectonophysics, 247, 157-160, https://doi.org/10.1016/0040-1951(95)98214-H

Menegon, L., Nasipuri, P., Stünitz, H., Behrens, H. and Ravna, E.K. 2011. Dry and strong quartz during deformation of the lower crust in the presence of melt. Journal of Geophysical Research: Solid Earth, 116, B10410, https://doi.org/ 10.1029/2011JB008371

Nachlas, W.O. and Hirth, G. 2015. Experimental constraints on the role of dynamic recrystallization on resetting the Ti-in-quartz thermobarometer. Journal of Geophysical Research: Solid Earth, 120, 8120-8137, https://doi. org/10.1002/2015JB012274

Olgaard, D.L. and Evans, B. 1988. Grain growth in synthetic marbles with added mica and water. Contributions to Mineralogy and Petrology, 100, 246-260, https://doi.org/10.1007/BF00373591

Ord, A. and Christie, J.M. 1984. Flow stresses from microstructures in mylonitic quartzites of the Moine Thrust zone, Assynt area, Scotland. Journal of Structural Geology, 6, 639-654, https://doi.org/10.1016/0191-8141(84) 90002-6

Parsons, A.J., Law, R.D., Lloyd, G.E., Phillips, R.J. and Searle, M.P. 2016. Thermo-kinematic evolution of the Annapurna-Dhaulagiri Himalaya, central Nepal: the composite orogenic system. Geochemistry, Geophysics, Geosystems, 17, 1511-1539, https://doi.org/10.1002/2015GC006184

Passchier, C.W. 1982. Pseudotachylyte and the development of ultramylonite bands in the Saint-Barthelemy Massif, French Pyrenees. Journal of Structural Geology, 4, https://doi.org/10.1016/0191-8141(82)90008-6

Passchier, C.W. and Trouw, R.A.J. 2005. Microtectonics. Springer, Berlin.

Pennacchioni, G. and Cesare, B. 1997. Ductile-brittle transition in pre-Alpine amphibolite facies mylonites during evolution from water-present to waterdeficient conditions (Mont Mary nappe, Italian Western Alps). Journal of Metamorphic Geology, 15, 777-791, https://doi.org/10.1111/j.1525-1314. 1997.00055.x

Pennacchioni, G. and Mancktelow, N.S. 2007. Nucleation and initial growth of a shear zone network within compositionally and structurally heterogeneous granitoids under amphibolite facies conditions. Journal of Structural Geology, 29, 1757-1780, https://doi.org/10.1016/j.jsg.2007.06.002

Pennacchioni, G. and Mancktelow, N.S. 2018. Small-scale ductile shear zones: neither extending, nor thickening, nor narrowing. Earth-Science Reviews, 184, 1-12, https://doi.org/10.1016/j.earscirev.2018.06.004

Poirier, J.-P. 1985. Creep of Crystals: High-temperature Deformation Processes in Metals, Ceramics and Minerals. Cambridge University Press, Cambridge.

Ramsay, J.G. and Graham, R.H. 1970. Strain variation in shear belts. Canadian Journal of Earth Sciences, 7, 786-813, https://doi.org/10.1139/e70-078

Ramsay, D.M., Sturt, B.A., Jansen, Ø, Andersen, T.B. and Sinha-Roy, S. 1985. The tectonostratigraphy of western Porsangerhalvøya, Finnmark, north Norway. In: Gee, D.G. and Sturt, B.A. (eds) The Caledonide Orogen: Scandinavia and Related Areas. Wiley, Chichester, 611-619.

Reginiussen, H., Ravna, E.K. and Berglund, K. 1995. Mafic dykes from Øksfjord, Seiland Igneous Province, northern Norway: geochemistry and palaeotectonic significance. Geological Magazine, 132, 667-681, https://doi. org/10.1017/S0016756800018902

Rice, A.H.N. and Frank, W. 2003. The early Caledonian (Finnmarkian) event reassessed in Finnmark: ${ }^{40} \mathrm{Ar} /{ }^{39} \mathrm{Ar}$ cleavage age data from NW Varangerhalvøya, N. Norway. Tectonophysics, 374, 219-236, https://doi. org/10.1016/S0040-1951(03)00240-3

Richter, B., Stünitz, H. and Heilbronner, R. 2016. Stresses and pressures at the quartz-to-coesite phase transformation in shear deformation experiments. Journal of Geophysical Research: Solid Earth, 121, 8015-8033, https://doi. org/10.1002/2016JB013084

Roberts, D. 1973. Geologisk kart over Norge, berggrunnskart. Hammerfest 1:250 000. Norges Geologiske Undersøkelse Bulletin, 61, 1-49.

Roberts, D. 2003. The Scandinavian Caledonides: event chronology, palaeogeographic settings and likely modern analogues. Tectonophysics, 365, 283-299, https://doi.org/10.1016/S0040-1951(03)00026-X

Roberts, R.J., Corfu, F., Torsvik, T.H., Ashwal, L.D. and Ramsay, D.M. $2006 a$. Short-lived mafic magmatism at $560-570 \mathrm{Ma}$ in the northern Norwegian Caledonides: U-Pb zircon ages from the Seiland Igneous Province. Geological Magazine, 143, 887-903, https://doi.org/10.1017/S0016756806002512 


\section{A. L. Lee et al.}

Roberts, R.J., Corfu, F., Torsvik, T.H., Hetherington, C.J. and Ashwal, L.D. 2006 $\mathrm{b}$. Age of alkaline rocks in the Seiland igneous province, northern Norway. Journal of the Geological Society, London, 167, 71-81, https://doi. org/10.1144/0016-76492009-014

Rosenberg, C.L. and Handy, M.R. 2005. Experimental deformation of partially melted granite revisited: implications for the continental crust. Journal of Metamorphic Geology, 23, 19-28, https://doi.org/10.1111/j.1525-1314.2005. 00555.x

Rushmer, T. 2001. Volume change during partial melting reactions: implications for melt extraction, melt geochemistry and crustal rheology. Tectonophysics, 342, 389-405, https://doi.org/10.1016/S0040-1951(01)00172-X

Sawyer, E.W. 1994. Melt segregation in the continental crust. Geology, 22, 1019-1022, https://doi.org/10.1130/0091-7613(1994)022<1019:MSITCC $>2$. 3. $\mathrm{CO} ; 2$

Schneider, C.A., Rasband, W.S. and Eliceiri, K.W. 2012. NIH image to ImageJ: 25 years of image analysis. Nature Methods, 9, 671-675, https://doi.org/10. 1038/nmeth.2089

Slagstad, T., Melezhik, V.A., Kirkland, C.L., Zwaan, K.B., Roberts, D., Gorokhov, I.M. and Fallick, A.E. 2006. Carbonate isotope chemostratigraphy suggests revisions to the geological history of the West Finnmark Caledonides, northern Norway. Journal of the Geological Society, London, 163, 277-289, https://doi.org/10.1144/0016-764905-021

Smith, J.R., Piazolo, S., Daczko, N.R. and Evans, L. 2015. The effect of pretectonic reaction and annealing extent on behaviour during subsequent deformation: insights from paired shear zones in the lower crust of Fiordland, New Zealand. Journal of Metamorphic Geology, 33, 557-577, https://doi.org/ 10.1111/jmg. 12132

Spear, F.S., Kohn, M.J. and Cheney, J.T. 1999. $P-T$ paths from anatectic pelites. Contributions to Mineralogy and Petrology, 134, 17-32, https://doi.org/10. 1007/s004100050466
Stipp, M. and Tullis, J. 2003. The recrystallized grain size piezometer for quartz. Geophysical Research Letters, 30, 1-5, https://doi.org/10.1029/ 2003GL018444

Stipp, M., Stünitz, H., Heilbronner, R. and Schmid, S.M. 2002. The eastern Tonale fault zone: a 'natural laboratory' for crystal plastic deformation of quartz over a temperature range from 250 to $700^{\circ} \mathrm{C}$. Journal of Structural Geology, 24, 1861-1884, https://doi.org/10.1016/S0191-8141 (02)00035-4

Sundvoll, B. and Roberts, D. 2003. A likely Ordovician age for the regional, penetrative cleavage in the Gaissa Nappe Complex, northern Norway. Norges Geologiske Undersøkelse Bulletin, 441, 51-59.

Tokle, L., Hirth, G. and Behr, W.M. 2019. Flow laws and fabric transitions in wet quartzite. Earth and Planetary Science Letters, 505, 152-161, https://doi.org/ 10.1016/j.eps1.2018.10.017

Twiss, R.J. 1977. Theory and applicability of a recrystallized grain size paleopiezometer. In: Wyss, M. (ed.) Stress in the Earth. Birkhäuser, Basel, 227-244.

Urai, J.L., Means, W.D. and Lister, G.S. 1986. Dynamic recrystallization of minerals. Mineral and Rock Deformation: Laboratory Studies, 36, 161-199, https://doi.org/10.1029/GM036p0161

Vanderhaeghe, O. 2009. Migmatites, granites and orogeny: Flow modes of partially-molten rocks and magmas associated with melt/solid segregation in orogenic belts. Tectonophysics, 477, 119-134, https://doi.org/10.1016/j.tecto. 2009.06.021

Vitale, S. and Mazzoli, S. 2008. Heterogeneous shear zone evolution: the role of shear strain hardening/softening. Journal of Structural Geology, 30, 1383-1395, https://doi.org/10.1016/j.jsg.2008.07.006

White, S. 1979. Grain and sub-grain size variations across a mylonite zone. Contributions to Mineralogy and Petrology, 70, 193-202, https://doi.org/10. 1007/BF00374448 